\title{
Renal Hemodynamics and Functional Changes during the Transition from Fetal to Newborn Life in Sheep
}

\author{
KENNETH T. NAKAMURA, G. PAUL MATHERNE, OLIVA J. MCWEENY, BRUCE A. SMITH, \\ AND JEAN E. ROBILLARD \\ Department of Pediatrics and the Cardiovascular Research Center, University of Iowa, Iowa City, Iowa 52242
}

\begin{abstract}
The effects of delivery on renal function and renal hemodynamics were studied in conscious and chronically instrumented fetal sheep. Each fetus was studied 1 $h$ before delivery and 1,4 , and $24 \mathrm{~h}$ following delivery by cesarean section. Delivery was not associated with significant changes in plasma renin activity, plasma angiotensin II, plasma aldosterone, and plasma arginine vasopressin concentrations when determined $1 \mathrm{~h}$ after birth. On the other hand, the transition from fetal to newborn life was accompanied by significant increases in plasma epinephrine and norepinephrine concentrations. No significant changes in renal blood flow velocity or in renal vascular resistance were observed during the transition from fetal to newborn life; percent changes in renal blood flow velocity and renal vascular resistance values were respectively 15.4 \pm 11 and $-2.4 \pm 1.0 \%$ at $1 \mathrm{~h}, 4.0 \pm 8.0$ and $5.8 \pm 9.1 \%$ at $4 \mathrm{~h}$, and $3.2 \pm 8.0$ and $9.7 \pm 13 \%$ at $24 \mathrm{~h}$. No significant changes in urinary flow rate, urine osmolality, free water clearance, and osmolar clearance were observed in the first $24 \mathrm{~h}$ following delivery. On the other hand, glomerular filtration rate increased 3-fold from $3.3 \pm 0.4 \mathrm{ml} / \mathrm{min}$ in fetuses to $10.1 \pm 1.2 \mathrm{ml} / \mathrm{min}$ in newborn lambs at $24 \mathrm{~h}$ of age. This rise in glomerular filtration rate was associated with significant decreases in urinary sodium excretion $\left(U_{\mathrm{Na}} \mathrm{V}\right.$ ) (from $36 \pm 7$ to $13 \pm 3 \mu \mathrm{Eq} / \mathrm{min}$ ) and fractional excretion of sodium $\left(\mathrm{FE}_{\mathrm{Na}}\right)($ from $7.6 \pm 0.9$ to $1.1 \pm 0.3 \%)$. In summary, present results demonstrate that transition from fetal to newborn life is associated with a rapid rise in glomerular filtration rate and an important decrease in urinary sodium excretion and fractional excretion of sodium. These changes seem to be independent of changes in renal blood flow velocity, renal vascular resistance, and blood pressure. (Pediatr Res 21: 229-234, 1987)
\end{abstract}

\section{Abbreviations}

RBFV, renal blood flow velocity

RVR, renal vascular resistance

GFR, glomerular filtration rate

Cosm, osmolar clearance

$\mathrm{CH}_{2} \mathrm{O}$, free water clearance

PRA, plasma renin activity

A-II, angiotensin II

AVP, arginine vasopressin

Uosm, urine osmolality

Received July 3, 1986; accepted October 14, 1986

Correspondence should be addressed to Jean E. Robillard, Department of Pediatrics, University of lowa College of Medicine, Iowa City, IA 52242.

Supported by United States Public Health Services Grants DK-38302, HD 20576, and HL-14388. K.T.N. is the recipient of Clinical Investigator Award HD 00670. G.P.M. is supported by Training Grant ST32-HL-07413.
$\mathrm{U}_{\mathrm{K}} \mathrm{V}$, urinary potassium

$\mathrm{FE}_{\mathrm{K}}$, fractional excretion of potassium

At birth many changes must occur to permit the kidney to assume control of water and electrolyte balance. Among these changes, rapid rise in renal blood flow and GFR (1) and important decline in sodium excretion $(2,3)$ have been described as contributing to the renal adaptation to postnatal life.

However, controversies still exist regarding the time sequence of each of these changes. The temporal relation between changes in renal hemodynamics and renal function during early transition from fetal to newborn life, as well as factors that modulate these changes have not been studied in detail. Furthermore, the specific contributions of various hormonal mediators to this process are not yet fully understood. However, key roles have been postulated for catecholamines, vasopressin, and the reninangiotensin-aldosterone system (4-7).

The present studies were designed to assess the effects of delivery on renal function at birth and to determine the relation between changes in renal hemodynamics, renal function, and circulatory vasoactive hormones. Conscious and chronically instrumented fetal sheep were studied sequentially before and immediately following delivery by cesarean section.

\section{METHODS}

Animal preparation and surgical procedures. The fetuses of 12 pregnant sheep of Dorset and Suffolk mixed breeding were studied just before birth (142-145 days gestation, term was 145 days) and immediately after delivery by cesarean section. Gestational ages were based on the induced ovulation technique as described previously (8).

Prior to surgery, the animals were fasted for $48 \mathrm{~h}$. Anesthesia of the ewe and surgery of the fetus were performed as described previously (9). Briefly, the pregnant ewe was anesthetized using a mixture of $1 \%$ halothane, $33 \% \mathrm{O}_{2}$, and $66 \% \mathrm{~N}_{2} \mathrm{O}$. The uterus was opened, and vascular polyethylene catheters (ID $0.86 \mathrm{~mm}$, OD $1.27 \mathrm{~mm}$ ), previously impregnated with dimethylpolysiloxane (Acumetric, Elizabethtown, CT) to reduce clotting, were inserted in both femoral veins and femoral arteries and positioned below the renal veins and arteries. A catheter was also secured in the amniotic cavity for intrauterine pressure measurements. Urine was collected via a catheter (3.5 French feeding tube) secured in the bladder via a cystostomy. Thereafter, through the same uterine incision, the left kidney was exposed through a left flank incision and a pulsed Doppler flow probe was secured around the left renal artery with care being taken not to interfere with renal innervation. After suturing all fetal incisions, the fetal 
membranes, uterine cavity, and maternal abdominal wall were closed in separate layers. All catheters were exteriorized through a subcutaneous tunnel and placed in a cloth pouch on the ewe's flank, after which the abdominal skin of the ewe was closed. At the end of surgery, ampicillin $(1 \mathrm{~g})$ was administered directly to the ewe and into the amniotic cavity.

Following surgery, the ewes were kept in a restricted area and fed a standard diet. The animals were usually standing and eating within $1 \mathrm{~h}$ after surgery. A recovery period of $72 \mathrm{~h}$ was allowed prior to performing experiments. Dexamethasone $(5 \mathrm{mg})$ was given intramuscularly $12 \mathrm{~h}$ before starting the experiment to prevent respiratory distress following delivery by cesarean section.

Before of each experiment, fetal weight was estimated according to the following formula: fetal body wt $(\mathrm{kg})=[0.096 \times$ gestational age (days)] $-9.223 ;(r=0.85, p<0.001)(9)$.

Physiological studies. During the physiological studies, the ewe was transferred into a small cart that permitted it to stand in an upright position. Each fetus studied received a priming dose of $10 \mu \mathrm{Ci}$ of $\left[{ }^{14} \mathrm{C}\right]$-inulin in $5 \%$ dextrose solution followed by a continuous intravenous infusion $(5 \mu \mathrm{Ci} / \mathrm{h})$ administered at a rate of $0.1 \mathrm{ml} / \mathrm{min}$ for determination of GFR as previously described (9). Following the start of the $\left[{ }^{14} \mathrm{C}\right]$-inulin infusion, an equilibration period of $1 \mathrm{~h}$ was allowed. After the equilibration period, a 30-min fetal urine collection period was performed.

Following the fetal urine collection period, the ewe was brought back to the surgery room and the fetus was delivered by cesarean section performed under spinal-epidural anesthesia using $10 \mathrm{ml}$ of $1 \%$ lidocaine. After delivery of the fetal lamb, the ewe was killed with a lethal dose of pentobarbital sodium (Somlethal, Midtech, Elwood, KS). During delivery, the intravenous infusion of $\left[{ }^{14} \mathrm{C}\right]$-inulin was continued and special care taken to keep all catheters and the Doppler flow probe intact.

Immediately following delivery the newborn lamb was placed under a standard overhead infant radiant warmer to keep body temperature between 38 and $39^{\circ} \mathrm{C}$, intubated orally and dried. Blood pressure, heart rate, renal blood flow velocity, and body temperature were monitored continuously during this recovery period. The newborn lamb was extubated in the first $20 \mathrm{~min}$ following delivery, weighed, and placed in a specially designed harness to be supported in a standing posture. In all lambs studied, experiments could be resumed $1 \mathrm{~h}$ postnatally. During the postnatal period, a continuous infusion of dextrose $10 \%$ and sodium chloride $0.2 \%$ solution containing $30 \mathrm{mEq} \mathrm{KCl}$ per liter was administered intravenously at a rate of $100 \mathrm{ml} / \mathrm{kg}$ per $24 \mathrm{~h}$. Thirty-minute urine collection periods were done at 1,4 , and 24 $\mathrm{h}$ postnatally.

During each urine collection period, urine was collected from the bladder for determination of urinary electrolytes $(\mathrm{Na}, \mathrm{K})$, Uosm, and urinary concentration of $\left[{ }^{14} \mathrm{C}\right]$-inulin. At the midpoint of each urine collection period, arterial blood was obtained for determination of plasma electrolyte concentrations ( $\mathrm{Na}, \mathrm{K}$ ), plasma osmolality, arterial blood gases $\left(\mathrm{pCO}_{2}\right.$ and $\left.\mathrm{pO}_{2}\right)$, arterial $\mathrm{pH}$, and plasma concentration of $\left[{ }^{14} \mathrm{C}\right]$-inulin. Blood for plasma AVP, PRA, A-II, plasma aldosterone, and plasma catecholamines (norepinephrine and epinephrine) concentrations was also collected during each period. To avoid any hemodynamic effect of sampling, fetal blood samples were replaced by infusing into the fetal arterial catheter an equal amount of maternal blood. In newborn lambs, blood samples were replaced with blood harvested from the fetal side of the placental circulation after the umbilical cord was cut, using the technique used in the fetus.

During each experiment, arterial, venous, and amniotic pressures (in fetuses) were recorded continuously using Statham P23Db pressure transducers (Statham Instruments, Schiller Park, IL). Fetal arterial and venous pressures were corrected relative to concomitant amniotic pressures. Heart rate was monitored with a cardiotachometer triggered from arterial pressure pulse waves.
Changes in RBF velocity was monitored continuously using the ultrasonic pulsed doppler flowmeter modified from the original design of Hartley and Cole (10) and constructed at the University of Iowa Bioengineering Resource Facility (11). The pulsed Doppler flow probe consisted of a silastic cuff around a 1 mm diameter $20-\mathrm{MHz}$ piezoelectric crystal with insulated copper wire leads. The technique for construction and use of the probes and application of the flowmeter have been described in detail (11). The validity of the pulsed Doppler flowmeter for use in determining percent changes in RBF velocity has previously been demonstrated $(11,12)$.

Analytical procedures. Arterial blood for $\mathrm{pH}, \mathrm{pCO}_{2}$, and $\mathrm{pO}_{2}$ was collected anaerobically in heparinized glass syringes and measurements were immediately determined with the appropriate $\mathrm{pH}, \mathrm{pCO}_{2}$, and $\mathrm{pO}_{2}$ electrodes at $39^{\circ} \mathrm{C}$ using a Radiometer PHM 72 MK2 acid-base analyzer (Radiometer Co., Copenhagen, Denmark). Plasma electrolytes ( $\mathrm{Na}, \mathrm{K}$ ), plasma osmolality, and concentrations of $\left[{ }^{14} \mathrm{C}\right]$-inulin in plasma and urine were determined as previously described (9). Radioimmunoassays previously established in our laboratories were used to measure PRA (13), plasma AVP $(9,14)$, angiotensin II (15), and aldosterone (16). Plasma norepinephrine and epinephrine concentrations were determined using a radioenzymatic assay (Cat-a-Kit, UpJohn Diagnostics, Kalamazoo, MI) described previously by Passon and Peuler (17).

Computations and data analysis. Percent changes (\%) in RBF velocity (\% $\triangle \mathrm{RBF})$ and renal vascular resistance (\% $\Delta \mathrm{RVR})$, using the Doppler flow probe, were calculated using the following formulas:

$$
\begin{gathered}
\% \Delta \mathrm{RBF}=\left[\left(\mathrm{E}_{\mathrm{DS}}-\mathrm{B}_{\mathrm{DS}}\right) / \mathrm{B}_{\mathrm{DS}}\right] \times 100 \\
\mathrm{RVR}=\mathrm{PP} / \mathrm{DS} \\
\% \Delta \mathrm{RVR}=\left[\left(\mathrm{RVR}_{\mathrm{E}}-\mathrm{RVR}_{\mathrm{B}}\right) / \mathrm{RVR}_{\mathrm{B}}\right] \times 100
\end{gathered}
$$

where $E_{D s}$ is the Doppler shift $(\mathrm{KHz})$ determined postnatally (experimental period); $B_{\mathrm{Ds}}$ is the Doppler shift $(\mathrm{KHz})$ during fetal life (baseline period); RVR is expressed arbitrarily in $\mathrm{mm}$ $\mathrm{Hg} / \mathrm{KHz} ; \mathrm{PP}$ is the renal perfusion pressure estimated to be equal to the mean aortic pressure $(\mathrm{mm} \mathrm{Hg})$ minus the mean vena cava pressure $(\mathrm{mm} \mathrm{Hg})$; DS is the Doppler shift in $\mathrm{KHz}$; and $\mathrm{RVR}_{\mathrm{E}}$ and $R V R_{B}$ are the RVR during experimental and baseline period, respectively.

Cosm was determined as follows: $\operatorname{Cosm}(\mathrm{ml} / \mathrm{min})=($ Uosm . V)/Posm, in which Uosm and Posm represent urine and plasma osmolality in mOsmol/ $\mathrm{kg} \mathrm{H}_{2} \mathrm{O}$ and $\mathrm{V}$, the urinary flow rate in $\mathrm{ml} / \mathrm{min}$. The solute $\mathrm{CH}_{2} \mathrm{O}$ was calculated as the difference between the urinary flow rate and the osmolar clearance: $\mathrm{CH}_{2} \mathrm{O}=$ V-Cosm.

Distribution-free multiple comparisons based on Friedman rank sums were used to compare all treatment groups (18). Values are expressed as means $\pm \mathrm{SE}$.

\section{RESULTS}

Effects of delivery on arterial blood values and circulating vasoactive substances (Tables 1 and 2, Fig. 1). The effects of delivery on arterial blood values are presented in Table 1 . It is shown that, $1 \mathrm{~h}$ following delivery, arterial $\mathrm{pH}$ was significantly lower than during fetal life. This level of metabolic acidosis was usually corrected by $4 \mathrm{~h}$ of postnatal age. The correction of the metabolic acidosis corresponded with a significant rise in arterial $\mathrm{pO}_{2}$ when compared to fetal values. Interestingly no significant changes in arterial $\mathrm{pCO}_{2}$ were observed. The transition from fetal to newborn life was not accompanied by significant changes in plasma electrolytes $(\mathrm{Na}, \mathrm{K})$, plasma osmolality, hematocrit, and plasma total protein concentration when newborn values were compared to fetal values.

The effects of delivery on the renin-angiotensin-aldosterone system and on plasma arginine vasopressin concentration are presented in Table 2. PRA and A-II concentration tended to be elevated $1 \mathrm{~h}$ after birth and to remain high during the first $24 \mathrm{~h}$ 
Table 1. Arterial blood values before and after birth in sheep (mean $\pm S E$ )

\begin{tabular}{|c|c|c|c|c|}
\hline & \multirow[b]{2}{*}{ Fetus } & \multicolumn{3}{|c|}{ Newborn } \\
\hline & & $1 \mathrm{~h}$ & $4 \mathrm{~h}$ & $24 \mathrm{~h}$ \\
\hline $\mathrm{pH}$ & $7.38 \pm 0.01$ & $7.30 \pm 0.02 *$ & $7.38 \pm 0.01 \dagger$ & $7.40 \pm 0.01 \dagger$ \\
\hline $\begin{array}{c}\mathrm{pCO}_{2}(\mathrm{~mm} \\
\mathrm{Hg})\end{array}$ & $42 \pm 2$ & $46 \pm 2$ & $40 \pm 1$ & $39 \pm 1$ \\
\hline $\mathrm{pO}_{2}(\mathrm{~mm} \mathrm{Hg})$ & $22 \pm 1$ & $52 \pm 4$ & $76 \pm 4^{*}$ & $86 \pm 4^{*} \uparrow$ \\
\hline $\mathrm{Na}$ (mEq/liter) & $144 \pm 1$ & $145 \pm 1$ & $146 \pm 1$ & $145 \pm 2$ \\
\hline $\mathrm{K}$ (mEq/liter) & $4.1 \pm 0.1$ & $4.1 \pm 0.1$ & $4.2 \pm 0.1$ & $4.1 \pm 0.2$ \\
\hline $\begin{array}{l}\text { Osmolality } \\
\left(\mathrm{mOsm}^{\prime} /\right. \\
\left.\mathrm{KgH}_{2} \mathrm{O}\right)\end{array}$ & $288 \pm 3$ & $292 \pm 1$ & $295 \pm 1$ & $292 \pm 2$ \\
\hline $\begin{array}{l}\text { Hematocrit } \\
(\%)\end{array}$ & $34 \pm 1$ & $32 \pm 1$ & $31 \pm 2$ & $31 \pm 2$ \\
\hline $\begin{array}{l}\text { Total proteins } \\
(\mathrm{g} / 100 \mathrm{ml})\end{array}$ & $3.8 \pm 0.1$ & $3.9 \pm 0.1$ & $4.0 \pm 0.1$ & $3.8 \pm 0.1$ \\
\hline
\end{tabular}

${ }^{*} p<0.05$ when fetal values are compared to newborn values.

$\dagger p<0.05$ when newborn values at $1 \mathrm{~h}$ are compared to newborn values at 4 or $24 \mathrm{~h}$.

Table 2. Renin, A-II, aldosterone, and vasopressin values before and after birth in sheep (mean $\pm S E$ )

\begin{tabular}{lcccc}
\hline & & \multicolumn{3}{c}{ Newborn } \\
\cline { 3 - 5 } & Fetus & $1 \mathrm{~h}$ & $4 \mathrm{~h}$ & $24 \mathrm{~h}$ \\
\hline PRA $(\mathrm{ng} / \mathrm{ml} / \mathrm{h})$ & $4.8 \pm 1.3$ & $10.4 \pm 2.7$ & $11.0 \pm 2.3^{*}$ & $10.1 \pm 2.7$ \\
A-II $(\mathrm{pg} / \mathrm{ml})$ & $80 \pm 16$ & $167 \pm 53$ & $103 \pm 21$ & $113 \pm 33$ \\
Aldosterone $(\mathrm{pg} / \mathrm{ml})$ & $40 \pm 5$ & $44 \pm 9$ & $54 \pm 13$ & $50 \pm 8$ \\
AVP $(\mu \mathrm{U} / \mathrm{ml})$ & $4.4 \pm 0.8$ & $9.3 \pm 3.1$ & $5.3 \pm 1.8$ & $2.5 \pm 0.2 \dagger$ \\
\hline
\end{tabular}

$* p<0.05$ when fetal values are compared to newborn values.

$\dagger p<0.05$ when newborn values at $1 \mathrm{~h}$ are compared to newborn values at 4 or $24 \mathrm{~h}$.
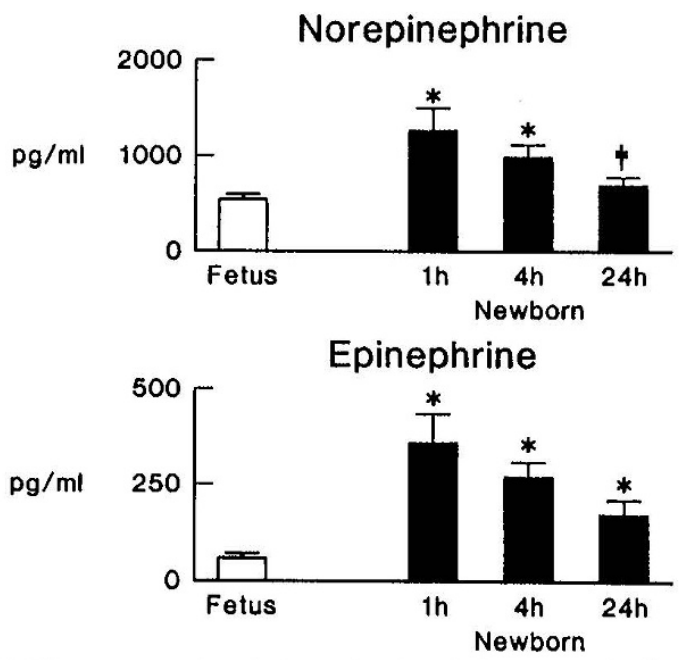

Fig. 1. Plasma norepinephrine and epinephrine concentrations before and after birth in sheep. ${ }^{*} p<0.05$ when fetal values are compared to newborn values. $\dagger p<0.05$ when newborn values at $1 \mathrm{~h}$ are compared to newborn values at 4 or $24 \mathrm{~h}$. Values are means $\pm \mathrm{SE}$.

of postnatal life. However, these changes were not found to be statistically significant, except when PRA values in newborn lambs at $4 \mathrm{~h}$ of age were compared to fetal values. No significant increases in plasma aldosterone and plasma AVP concentrations were observed when newborn levels were compared to fetal values.

On the other hand, the transition from fetal to newborn life was accompanied by significant increases in plasma catechol- amine (Fig. 1) concentrations. Both epinephrine and norepinephrine concentrations were significantly higher than fetal values at $1 \mathrm{~h}$ after birth. These levels tended to decrease thereafter, but remained elevated during the first $24 \mathrm{~h}$ after birth.

Effects of delivery on arterial blood pressure, heart rate, and renal hemodynamics (Fig. 2). The transition period from fetal to newborn life was not associated with significant changes in mean arterial blood pressure but was accompanied by a significant rise in heart rate in newborn lambs at $1 \mathrm{~h}$ of age. No significant changes in RBFV or in RVR were observed during the transition from fetal to newborn life. Changes in newborn RBFV and RVR, when compared to fetal values, were respectively $15.4 \pm 11$ and $-2.4 \pm 1.0 \%$ at $1 \mathrm{~h}, 4.0 \pm 8.0$ and $5.8 \pm 9.1 \%$ at $4 \mathrm{~h}$, and $3.2 \pm$ 8.0 and $9.7 \pm 13 \%$ at $24 \mathrm{~h}$, and were found to not be statistically significant.

Effects of delivery on renal function values (Table 3, Fig. 3). No significant changes in urinary flow rate, Uosm, $\mathrm{CH}_{2} \mathrm{O}$, and Cosm were observed during the transition from fetal to newborn life (Table 3). On the other hand, the GFR increased 3-fold during the first $24 \mathrm{~h}$ following delivery, from $3.3 \pm 0.4 \mathrm{ml} / \mathrm{min}$ in fetuses to $10.1 \pm 1.2 \mathrm{ml} / \mathrm{min}$ in newborn lambs at $24 \mathrm{~h}$ of age (Table 3 and Fig. 3). Significant decreases in $U_{N a} V$ and $F_{\mathrm{Na}}$ were also observed following delivery (Table 3 and Fig. 3). $U_{\mathrm{Na}} \mathrm{V}$ and $\mathrm{FE}_{\mathrm{Na}}$ decreased respectively from $36 \pm 7 \mu \mathrm{Eq} / \mathrm{min}$ and 7.6 $\pm 0.9 \%$ in fetuses to $13 \pm 3 \mu \mathrm{Eq} / \mathrm{min}$ and $1.1 \pm 0.3 \%$ in $24-\mathrm{h}$ old newborn lambs. No significant changes in $U_{K} V$ and $F E_{K}$ were observed during the first $24 \mathrm{~h}$ following birth (Table 3 ).

\section{DISCUSSION}

Renin, angiotensin, vasopressin, and catecholamines during transition from fetal to newborn life. It has been suggested that the renin-angiotensin system and circulating catecholamines and vasopressin may play an important role during postnatal adaptation (19). Studies in newborn infants $(20-22)$ and newborn animals $(4,6,23)$ have shown that PRA, plasma A-II, plasma AVP, and plasma catecholamine concentrations increase following vaginal delivery. In the present study, a small but significant rise in PRA is observed $4 \mathrm{~h}$ postnatally when compared to fetal values. On the other hand, despite a trend toward increases in plasma A-II levels after birth, no significant changes are observed. Similarly, no increases in plasma AVP concentration are demonstrated when newborn values are compared to fetal values. The fact that fetuses were delivered by cesarean section before induction of labor and that the first blood sample was taken $1 \mathrm{~h}$ after birth may explain the small rise in PRA and the absence of significant increases in plasma A-II and plasma AVP concentra-
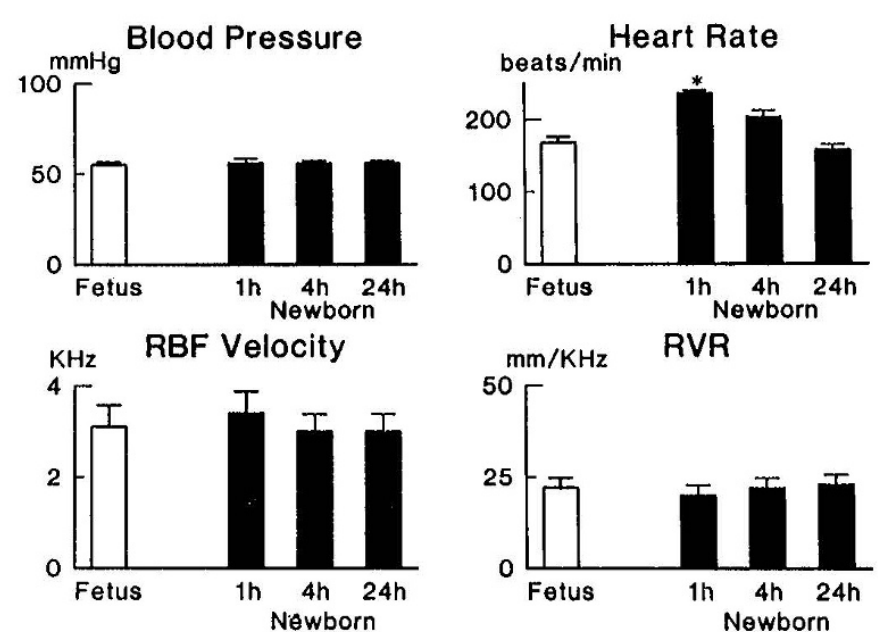

Fig. 2. Arterial blood pressure and renal hemodynamic values before and after birth in sheep. ${ }^{*} p<0.05$ when fetal values are compared to newborn values. Values are mean $\pm \mathrm{SE}$. 
Table 3. Renal function values before and after birth in sheep (mean $\pm S E)^{*}$

\begin{tabular}{|c|c|c|c|c|}
\hline & \multirow[b]{2}{*}{ Fetus } & \multicolumn{3}{|c|}{ Newborn } \\
\hline & & $1 \mathrm{~h}$ & $4 \mathrm{~h}$ & $24 \mathrm{~h}$ \\
\hline $\mathrm{UFR}(\mathrm{ml} / \mathrm{min})$ & $0.74 \pm 0.09$ & $0.87 \pm 0.17$ & $0.58 \pm 0.05$ & $0.61 \pm 0.10$ \\
\hline $\mathrm{GFR}(\mathrm{ml} / \mathrm{min})$ & $3.29 \pm 0.38$ & $5.37 \pm 0.92$ & $7.65 \pm 1.23 \dagger$ & $10.06 \pm 1.18 \dagger$ \\
\hline $\mathrm{U}_{\mathrm{NA}} V(\mu \mathrm{Eg} / \mathrm{min})$ & $35.8 \pm 6.6$ & $59.9 \pm 14.1$ & $20.8 \pm 4.1$ & $12.7 \pm 3.5+ \pm$ \\
\hline $\mathrm{FE}_{\mathrm{Na}}(\%)$ & $7.6 \pm 0.9$ & $8.9 \pm 2.0$ & $3.1 \pm 1.0 \dagger$ & $1.1 \pm 0.3 \psi^{+}$ \\
\hline $\mathrm{U}_{\mathrm{K}} \mathrm{V}(\mu \mathrm{Eq} / \mathrm{min})$ & $11.1 \pm 2.6$ & $10.1 \pm 1.5$ & $17.6 \pm 2.6$ & $14.5 \pm 3.0^{\circ}$ \\
\hline $\mathrm{FE}_{\mathrm{K}}(\%)$ & $89.8 \pm 26.2$ & $50.3 \pm 5.8$ & $75.4 \pm 24.2$ & $39.9 \pm 7.7$ \\
\hline Uosm $\left(\mathrm{mOsm} / \mathrm{kg} \mathrm{H}_{2} \mathrm{O}\right)$ & $194 \pm 38$ & $257 \pm 48$ & $212 \pm 47$ & $150 \pm 20$ \\
\hline $\mathrm{CH}_{2} \mathrm{O}(\mathrm{ml} / \mathrm{min})$ & $0.33 \pm 0.10$ & $0.32 \pm 0.12$ & $0.22 \pm 0.07$ & $0.32 \pm 0.07$ \\
\hline $\operatorname{Cosm}(\mathrm{ml} / \mathrm{min})$ & $0.41 \pm 0.07$ & $0.55 \pm 0.10$ & $0.36 \pm 0.06$ & $0.29 \pm 0.06$ \\
\hline
\end{tabular}

* UFR, urinary flow rate; UV, urinary excretion rate; $F E_{\mathrm{Na}}$, fractional excretion of sodium.

$\dagger p<0.05$ when fetal values are compared to newborn values.

$\ddagger p<0.05$ when newborn values at $1 \mathrm{~h}$ are compared to newborn values at 4 or $24 \mathrm{~h}$.

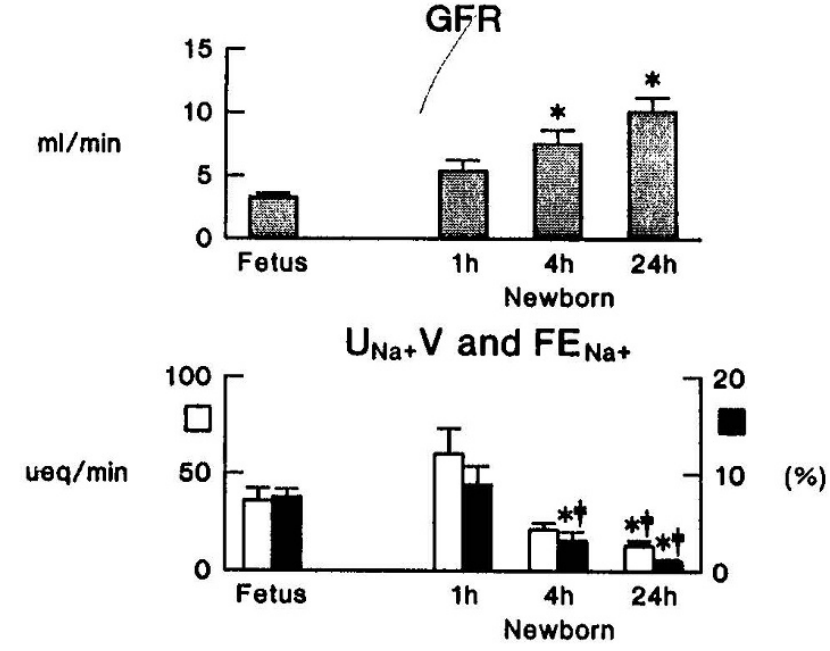

Fig. 3. GFR and urinary sodium excretion before and after birth in sheep. ${ }^{*} p<0.05$ when fetal values are compared to newborn values. $\dagger p$ $<0.05$ when newborn values at $1 \mathrm{~h}$ are compared to newborn values at 4 or $24 \mathrm{~h}$. $\mathrm{U}_{\mathrm{Na}} \mathrm{V}$, urinary excretion rate in $\mu \mathrm{Eq} / \mathrm{min} \square ; \mathrm{FE}_{\mathrm{Na}}$, fractional excretion in $\%$. Values are mean $\pm \mathrm{SE}$.

tions in the present study. Supporting the present results, previous studies $(6,7,21,24)$ have shown that PRA as well as plasma A-II and plasma AVP concentrations are lower in infants delivered by cesarean section than vaginally.

The present study also demonstrates, in agreement with previous results (4), that transition from fetal to newborn life is accompanied by a significant rise in plasma epinephrine and norepinephrine concentrations. Factors contributing to this rise were not investigated. However, it has been suggested that mechanical stress during labor, fetal hypoxemia, cord cutting, and cold exposure contribute to the rise in circulating catecholamines at birth $(20,25,26)$. Moreover, one may speculate that these levels could have been higher if fetuses had been allowed to delivery vaginally.

Renal hemodynamics and GFR during the transition from fetal to newborn life. The present study demonstrates that transition from fetal to newborn life is characterized by a significant increase in GFR not associated with significant changes in RBFV. Factors contributing to this increase in GFR have not been studied in detail. However, since no significant rise in arterial blood pressure is observed during the first $24 \mathrm{~h}$ of postnatal life, it seems unlikely that changes in renal perfusion pressure contribute to this rise in GFR. On the other hand, one may suggest that the increase in GFR at the time of birth may be dependent on intrarenal redistribution of blood flow resulting in a rise in glomerular plasma flow in nephrons localized in the outer cortex. In favor of this hypothesis, Aperia et al. (27) demonstrated that, while no significant differences in total renal blood flow were observed between fetal and newborn lambs immediately after cord clamping, intrarenal blood flow distribution to superficial glomeruli increases at birth in absolute terms $(\mathrm{nl} / \mathrm{min})$ and in relation to blood flow to the juxtamedullary glomeruli. Moreover, it has been suggested that the rate of glomerular plasma flow is the primary factor controlling GFR in immature animals $(28,29)$. One may also speculate that the low arterial $\mathrm{pO}_{2}$ before birth might contribute to the relatively low outer cortical perfusion in fetal sheep, since low $\mathrm{pO}_{2}$ in adult animals has been shown to result in redistribution of blood flow toward the inner cortex (30).

It has been suggested that the changes in intrarenal hemodynamics which may modulate the increase in GFR observed postnatally might be dependent on changes in vasoactive substances observed at the time of birth (1). In this respect, the renin-angiotensin system which is highly stimulated during early postnatal life when compared to adult values (31) may influence renal hemodynamics and GFR during the postnatal period. However, the absence of significant changes in plasma A-II concentrations in the present study is against a role for the reninangiotensin system to influence changes in renal hemodynamics and renal function during the transition from fetal to newborn life. In this respect, the present findings confirm previous results suggesting that the renin-angiotensin system plays a minor role in controlling GFR in newborn animals $(32,33)$.

On the other hand, the rise in GFR observed during the first $24 \mathrm{~h}$ of postnatal life follows closely the decline in plasma epinephrine and norepinephrine concentrations, suggesting that catecholamines may influence GFR during the transition from fetal to newborn life. However, previous studies in adult animals indicate that norepinephrine causes afferent and efferent arteriolar vasoconstriction thereby causing an increase in the transmembrane hydraulic pressure difference and a fall in glomerular plasma flow, two offsetting events that should leave GFR unchanged (34). Based on these studies and on the fact that RBF velocity does not change immediately after birth, it would be unlikely that the changes observed in plasma catecholamines during the transition from fetal to newborn life influence GFR postnatally.

Finally, prenatal administration of dexamethasone to the ewe to prevent respiratory distress in newborn animals could have influenced the changes observed in glomerular filtration rate postnatally. Stonestreet et al. (35) have suggested that fetal administration of glucocorticoid stimulates functional maturation of the kidney and increases GFR in newborn lambs. On the other hand, MacKintosh et al. (36) observed that prenatal ad- 
ministration of glucocorticoids in humans was not associated with significant changes in GFR postnatally.

Urinary sodium excretion during transition from fetal to newborn life. The present study demonstrates that transition from fetal to newborn life is associated with a rapid increase in renal tubular sodium reabsorption. This rapid rise in sodium reabsorption occurs almost immediately after birth and is not associated with significant changes in plasma aldosterone concentrations. Moreover, the decline in sodium excretion happens despite a significant rise in GFR, which should create a tendency toward sodium loss.

Factors that could modulate these changes have not been studied in detail. However, one may speculate that first, the rapid decline in sodium excretion at birth may be related to cessation of abundant placental supplies of water and electrolytes and secondary contraction of the extracellular fluid volume. In favor of this hypothesis, we have previously demonstrated that contraction of extracellular fluid volume produces a significant rise in sodium reabsorption in fetal sheep (37). Thus, one may speculate that the loss of the high fetal extracellular fluid volume immediately after birth may be a major determinant of the increase in sodium reabsorption by the newborn kidney. Second, since plasma aldosterone concentration does not change significantly after birth, it seems unlikely that aldosterone plays an important role in the substantial fall in the fractional excretion of sodium observed during the transition from fetal to newborn life. In favor of this hypothesis it has been demonstrated that newborn rats ( $1 \mathrm{wk}$ old) are somewhat insensitive to aldosterone when compared to more mature animals ( 2 and 4 wk old) (38). On the other hand, the present results are somewhat different than previous studies (5) which suggest that aldosterone plays an important role in the retention of sodium during infancy. Third, one may suggest that the rise in arterial $\mathrm{O}_{2}$ content and renal oxygen delivery associated with postnatal life increases the renal energy available for sodium reabsorption and the ability of the newborn kidney to reabsorb sodium. Studies by Iwamoto $e t$ al. (39) have shown that oxygen delivered to the newborn sheep kidney is about five to seven times that to the fetal kidney and that there is a relationship between the amount of $\mathrm{Na}^{+}$reabsorbed and renal $\mathrm{O}_{2}$ delivery and $\mathrm{O}_{2}$ consumption, confirming previous results in newborn rats (40). Finally, rapid increase in Na-KATPase in proximal tubular cells immediately after birth may contribute to the increase in $\mathrm{Na}^{+}$reabsorption during the transition from fetal to newborn life (41). Moreover, administration of dexamethasone to the ewe to prevent respiratory distress in the newborn lamb could have stimulated the activity of Na-KATPase (42). On the other hand, it has been suggested that changes in Na-K-ATPase activity result from an increase in intracellular $\mathrm{Na}^{+}$concentration and therefore follow the maturation of transport process (43).

In summary, the present study demonstrates 1) that PRA, plasma A-II, plasma aldosterone, and plasma AVP concentrations are not significantly elevated $1 \mathrm{~h}$ after delivery by cesarean section when compared to fetal values; 2) that significant increases in plasma norepinephrine and epinephrine concentrations are observed during the first $24 \mathrm{~h}$ after delivery; 3 ) that transition from fetal to newborn life is characterized by a significant increase in GFR not associated with significant changes in RBFV and RVF; and, 4) that a rapid rise in sodium reabsorption occurs almost immediately after birth and is not associated with significant changes in plasma aldosterone concentration.

\section{REFERENCES}

1. Spitzer A 1978 Renal physiology and functional development. In: Edelmann Jr CM (ed) Pediatric Kidney Disease. Little, Brown and Company, Boston, pp 25-128

2. Merlet-Benichou C, de Rouffignac C 1977 Renal clearance studies in fetal and young guinea pigs: effect of salt loading. Am J Physiol 232:F178-F185

3. Robillard JE, Ramberg E, Sessions C, Consamus B, VanOrden D, Weismann

D, Smith FG Jr 1980 Role of aldosterone on renal sodium and potassium excretion during fetal life and newborn period. Dev Pharmacol Ther 1:201216

4. Padbury JF, Polk DH, Newnham JP, Lam RW 1985 Neonatal adaptation: greater sympathoadrenal response in preterm than full-term fetal sheep at birth. Am J Physiol 248:E443-E449

5. Spitzer A 1982 The role of the kidney in sodium homeostasis during maturation. Kidney Intern 21:539-545

6. Leffler CW, Crofton J, Brooks DP, Share L, Hessler JR, Green RS 1985 Changes in plasma arginine vasopressin during transition from fetus to newborn following minimal trauma delivery of lambs and goats. Biol Neonate 48:43-48

7. Mott JC 1975 The place of the renin-angiotensin system before and after birth Br Med Bull 31:44-50

8. Jennings JJ, Crowley JP 1972 The influence of mating management on fertility in ewes following progesterone-PMS treatment. Vet Rec 90:495-498

9. Robillard JE, Weitzman RE 1980 Developmental aspects of the fetal renal response to exogenous arginine vasopressin. Am J Physiol 238:F407-F414

10. Hartley CJ, Cole JS 1974 An ultrasonic pulsed doppler system for measuring blood flow in small vessels. J Appl Physiol 37:626-629

11. Haywood JR, Shaffer RA, Fastenow C, Fink GD, Brody MJ 1981 Regional blood flow measurement with pulsed doppler flowmeter in the conscious rat. Am J Physiol 241:H273-H278

12. Robillard JE, Nakamura KT, DiBona GF 1986 Effects of renal denervation on renal responses to hypoxemia in fetal lambs. Am J Physiol 250:F294F301

13. Haber E, Koerner T, Page LB, Kliman B, Purnobe A 1969 Application of a radioimmunoassay for angiotensin $I$ to the physiologic measurements of plasma renin activity in normal human subjects. J Clin Endocrinol Metab 29:1349-1355

14. Skowsky WR, Rosenbloom AA, Fisher DA 1974 Radioimmunoassay measurement of arginine vasopressin in serum: development and application. J Clin Endocrinol Metab 38:278-287

15. Cain MD, Coghlan JP, Catt KJ 1972 Measurement of angiotensin II in blood by radioimmunoassay. Clin Chem Acta 39:21-34

16. Ito T, Woo J, Haning R, Horton R 1972 A radioimmunoassay for aldosterone in human peripheral plasma including a comparison of alternate techniques. J Clin Endocrinol Metb 34:106-112

17. Passon PG, Peuler JD 1973 A simplified radiometric assay for plasma norepinephrine and epinephrine. Anal Biochem 51:618-631

18. Hollander M, Wolfe DA 1973 Non-Parametric Statistical Methods. John Wiley \& Sons, New York, pp 138-184

19. Heymann MA, Iwamoto HS, Rudolph AM 1981 Factors affecting changes in the neonatal systemic circulation. Ann Rev Physiol 43:371-383

20. Eliot RJ, Lam R, Leake RD, Hobel CJ, Fisher DA 1980 Plasma catecholamine concentrations in infants at birth and during the first 48 hours of life. $J$ Pediatr 96:311-315

21. Lumbers ER, Reid GC 1977 Effects of vaginal delivery and caesarean section on plasma renin activity and angiotensin II levels in human umbilical cord blood. Biol Neonate 31:127-133

22. Pohjavuori M, Raivio KO 1985 The effects of acute and chronic perinatal stress on plasma vasopressin concentration and renin activity at birth. Biol Neonate 47:259-264

23. Broughton-Pipkin F, Kirkpatrick SM, Lumbers ER, Mott JC 1974 Renin and angiotensin-like levels in foetal, newborn and adult sheep. J Physiol (Lond) 241:575-588

24. Pohjavuori M 1983 Obstetric determinants of vasopressin levels and plasma renin activity at birth. J Pediatr 103:966 -968

25. Lagercrantz H, Bistoletti $P 1977$ Catecholamine release in the newborn infant at birth. Pediatr Res 11:889-893

26. Jones CM, Greiss FC Jr 1982 The effect of labor on maternal and fetal circulating catecholamines. Am J Obstet Gynecol 144:149-153

27. Aperia A, Broberger O, Herin P, Joelsson I 1977 Renal hemodynamics in the perinatal period. A study in lambs. Acta Physiol Scand 99:261-269

28. Aperia A, Herin P 1975 Development of glomerular perfusion rate and nephron filtration rate in rats 17-60 days old. Am J Physiol 228:1319-1325

29. Ichikawa I, Maddox DA, Brenner BM 1979 Maturational development of glomerular ultrafiltration in the rat. Am J Physiol 236:F465-F471

30. Barger AC 1966 Renal hemodynamic factors in congestive heart failure. Ann NY Acad Sci 139:276-284

31. Mott JC 1979 The renin-angiotensin-aldosterone system in pregnancy and its relation to that of the fetus and newborn. In: Nitzan M (Ed) Pediatric and Adolescent Endocrinology, Vol 5. S. Karger, New York, pp 126-145

32. Osborn JL, Hook JB, Bailie MD 1980 Effect of saralasin and indomethacin on renal function in developing piglets. Am J Physiol 238:R438-R442

33. Robillard JE, Weismann DN, Gomez RA, Ayres NA, Lawton WJ; VanOrden DE 1983 Renal and adrenal responses to converting enzyme inhibition in fetal and newborn life. Am J Physiol 244:R249-R256

34. Brenner BM, Badr KR, Schor N, Ichikawa I 1980 Hormonal influences on glomerular filtration. Miner Electrolyte Metab 4:49-56

35. Stonestreet BS, Hansen NB, Laptook AB, Oh W 1983 Glucocorticoid accelerates renal functional maturation in fetal lambs. Early. Hum Dev 8:331341

36. MacKintosh D, Baird-Lambert J, Drage D, Buchanan N 1985 Effects of prenatal glucocorticoids on renal maturation in newborn infants. Dev Pharmacol Ther 8:107-114

37. Robillard JE, Sessions C, Burmeister L, Smith FG Jr 1977 Influence of fetal 
extracellular volume contraction on renal reabsorption of bicarbonate in fetal lambs. Pediatr Res 11:649-655

38. Stephenson G, Hammet M, Hadaway G, Funder JW 1984 Ontogeny of renal mineralocorticoid receptors and urinary electrolyte responses in the rat. Am J Physiol 247:F665-F671

39. Iwamoto HS, Oh W, Rudolph AM 1985 Renal metabolism in fetal and newborn sheep. In: Jones CT, Nathanielsz PW (eds) The Physiological Development of the Fetus and Newborn. Academic Press, Orlando, pp 3740

40. Elinder G, Aperia A 1982 Renal oxygen consumption and sodium reabsorption during isotonic volume expansion in the developing rat. Pediatr Res 16:351353

41. Aperia A, Larsson L 1984 Induced development of proximal tubular NaKATPase, basolateral cell membranes and fluid reabsorption. Acta Physiol Scand 121:133-141

42. Igarashi Y, Aperia A, Larsson L, Zetterstrom R 1983 Effect of betamethasone on Na-K-ATPase activity and basal and lateral cell membranes in proximal tubular cells during early development. Am J Physiol 245:F232-F237

43. Schwartz GJ, Evan AP 1984 Development of solute transport in rabbit proximal tubule. III. Na-K-ATPase activity. Am J Physiol 246:F845-F852

\section{Announcement}

\section{Annual Meeting}

The American Pediatric Society and The Society for Pediatric Research will hold the meetings on April 27-April 30, 1987 at the Disneyland Hotel, Anaheim, CA.

For information, contact: Audrey Brown, M.D., Secretary-Treasurer, American Pediatric Society, SUNY, Health Science Center at Brooklyn, Dept. of Pediatrics, Box 49, 450 Clarkson Avenue, Brooklyn, NY 11203 (212)270-1692 OR Mrs. Debbie Wogenrich, Office of the Executive Secretary, Society for Pediatric Research, Dept. of Pediatrics, University of New Mexico School of Medicine, Albuquerque, NM 87131 (505)277-6629 